\section{PHILIPPIKA}

Altertumswissenschaftliche Abhandlungen

Contributions to the Study

of Ancient World Cultures

Herausgegeben von/Edited by Joachim Hengstl, Elizabeth Irwin, Andrea Jördens, Torsten Mattern, iobert Rollinger, Kai Ruffing, Orell Witthuhn

118

\section{Change, Continuity, and Connectivity}

North-Eastern Mediterranean at the turn of the Bronze Age and in the early Iron Age

\section{Edited by}

Łukasz Niesiołowski-Spanò and Marek Węcowski 


\title{
Approaches to Mycenaean-Hittite Interconnections in the Late Bronze Age ${ }^{1}$
}

\author{
Piotr Taracha
}

This paper deals with both, archaeological evidence for cultural links between the Mycenaean world and western Anatolia in the Late Bronze Age, and the Ahhiyawa problem that is based on nearly thirty Hittite texts (among the thousands that had been found in the archives of the Hittite capital Hattusa, modern Boğazkale about $150 \mathrm{~km}$ as the crow flies east of Ankara), in which the term "Ahhiya(wa)" appears. ${ }^{2}$ Both issues are indeed connected and must not be treated separately, although there are still many scholars to do so. What is more, concerning the former "there is an unfortunate tendency in much recent work on interconnections to transform hypothesis into established fact," ${ }^{3}$ while the latter "still remains unsolved and unanswered almost a century after it was first introduced." Beckman, Bryce, and Cline concur with the opinio communis in accepting the designation of the Mycenaeans by the Hittites as "Ahhiyawa" (and an earlier version "Ahhiya"); still, they endorse and deliberate on the question:

If so, was it meant to be a reference to all of the Mycenaeans on mainland Greece and elsewhere? Or, since we know that the Mycenaeans were split up into what were essentially a series of small city-states, was it a reference only to those in a specific region or locality, such as the Peloponnese (e.g., Mycenae), Boeotia (e.g., Thebes), Rhodes, or western Anatolia? Could the meaning have changed over time, as Hittite relations with these foreigners evolved over the centuries?

From a methodological perspective it is essential to understand that the Ahhiyawa texts and the archaeological evidence for Mycenaean presence in southwestern Anatolia are naturally of different informative value, though they do not contradict each other, and if asked properly, they can give a suggestive picture of western Anatolia in the Late Bronze Age and of Mycenaean-Hittite interconnections there. Another issue is whether the littoral of western Anatolia (including the offshore islands), from the perspective of the Mycenaean culture, should be considered an "interface," a border zone (i.e., "a transitional area that extends from the limits of the core zone of a sedentary society to the limits of its effective control, political or otherwise" ${ }^{\text {") }}$, or a frontier area that, as separated by a body of water, is commonly referred to as colonies or enclaves. ${ }^{7}$ Feuer gives the following definitions:

1 Research related to the subject of this paper was possible thanks to the grant of the National Science Centre (NCN, Poland) no. 2015/19/P/HS3/04161.

2 Fischer 2010; Beckman, Bryce, Cline 20II; cf. also Taracha 2006; 2009.

3 Rehak 1997: 40I.

4 Beckman, Bryce, Cline 20II: I, 267-83, for the most recent discussion of Mycenaean-Hittite interconnection

5 Beckman, Bryce, Cline 20II: 1.

6 Feuer 2011: 517 .

7 E.g., Tartaron 2005. Cf. also Branigan $198 \mathrm{I}$; 1984. 
In the intermediate border zone, there are large numbers of other ethnic groups, and while members of these groups tend to interact primarily with one another, there is greater interaction with others as well; here, ethnic markers assume greater salience because the need for contrast with other groups is stronger. In the frontier zone, members of the core ethnic group are often a minority, and although they may interact a good deal with fellow members within an enclave, they are likely to be surrounded by and interact regularly with those of other ethnic and/or cultural groups. ${ }^{8}$

$\mathrm{He}$ adds:

Because groups or individuals from different groups encounter one another regularly in peripheral zones and because political and economic control, at least in preindustrial times, is more tenuous, border and frontier areas are almost by definition liminal zones wherein interaction and change can occur more readily than elsewhere. Within this contact zone, a condition of indeterminacy exists that has been variously characterized as a third space, middle ground, or contested ground. Although each of these concepts is slightly different, they overlap in sharing the notion of open-ended possibilities whereby the inhabitants of these regions have the opportunity to negotiate an identity or identities through the agency of choice. ... One common form of interaction is trade or exchange. ... A second process common in marginal zones is conflict, including warfare. ... Other processes intimately associated with ethnicity and culture are acculturation, creolization, syncretism, hybridization, transculturation, emulation, and assimilation. ... In addition to exchange, one of the primary means of acculturation or assimilation is intermarriage, and it has been noted that one thing that typically crosses boundaries - ethnic or otherwise - is people.?

As a matter of fact, the foregoing criteria and concepts that have been put forward in the theoretical discussion on peripheral regions may well be applied to ethnic, cultural, and political conditions of western Anatolia in the Late Bronze Age. There are issues such as Mycenaean cultural and ethnic diacritics, trade or exchange, and processes of acculturation, emulation, and assimilation that can be referred to and discussed based primarily, if not exclusively, on the archaeological data. Yet, from Hittite texts we get further information, scarce and not always clear as it is, on the changing political situation in the region that was split up generally into small city-states that could join in an emergency, mostly when facing the power policy and military campaigns of the Hittite great kings, into coalitions and confederacies. One of the latter (with the capital Apasa, identified by some scholars with modern Ayasuluk near Ephesus), called Arzawa in Hittite sources, became temporarily a regional power ruled by a Luwian dynasty that controlled vast territories in western Anatolia and some of the offshore islands. During its heyday in the first half of the fourteenth century BC, Arzawa maintained diplomatic contacts with Amenhotep III, ${ }^{10}$ and about $132 \mathrm{I}$, after a period of vassal subordination to the Hittites due to the conquests of Suppiluliuma I (ca. 1357-1322), the last Arzawan king, Uhha-ziti, rebelled once more against the new Hittite ruler, Mursili II (1322-ca. 1290), forming an alliance with the king of Ahhiyawa, which ended in the ultimate fall of the confederacy (1319). ${ }^{11}$

8 Feuer 2011: 518. Cf. also Feuer 1999; 2003.

Feuer 2011: 518,519 , with references to the archaeological literature that offers a theoretical discussion of the foregoing issues.

10 Cline 1998.

11 Heinhold-Krahmer 1977; cf. also Hawkins 2009: 74-75, 79-80. 
We are told also about local conflicts and rebellions of Hittite vassals, sometimes instigated by the Ahhiyawans, Hittite diplomatic contacts both with the western Anatolian vassals and the kingdom of Ahhiyawa, ${ }^{12}$ and even about what Feuer designated as the opportunity for the inhabitants of the region, both members of the elites and men of humble birth, "to negotiate an identity or identities through the agency of choice;" in reality, however, due to perpetual conflicts, they were often forced into accepting the change of suzerain, as, for instance, in the case of the purple-dyers of the Hittite king (most likely Muwattali II, ca. 1290-1272) and Manapa-Tarhunta, Hittite vassal in the Seha River Land (probably the Caicus valley), who came to Lazpa (Lesbos) "across the sea" and then, after the smiting of the island by an Ahhiyawan vassal Atpa of Millawanda, became subordinates of the latter. ${ }^{13}$ In this case, ethnicity or group identity of the men had no bearing upon the matter. Furthermore, if the Mycenaeans can be equated with the Ahhiyawans, then - as Beckman, Bryce, and Cline state:

[W] are able to trace not only the overall history of Mycenaean-Hittite relations over the course of the Late Bronze Age, but also parts of the careers of individuals such as the rascally Piyamaradu and the wily Attarissiya, as well as a portion of the history of individual places such as Millawanda / Milawata (Miletus) and Wilusa (probably Troy and/or the Troad). ${ }^{14}$

There is no need here to restate the comments that have been made by other scholars concerning Ahhiyawa in Hittite texts, nor shall I go again over the countless interpretations of the archaeological evidence for the Mycenaean presence in western Anatolia. ${ }^{15}$ What is my aim in the following is rather to pull out some issues concerning both the archaeological and textual data that might be augmented by additional considerations.

Recent advances in anthropology and archaeology focus on the assumption that prehistoric people present themselves through their material culture. ${ }^{16}$ However, as Feuer remarks:

Compared with diacritics such as language, religion, and ideology, the relationship of material culture to ethnicity is more problematic. ... Moreover, the effects of choice, contingency, and variability make it quite difficult to infer or predict which aspects of material culture in a given situation will be considered more salient. ${ }^{17}$

In the previous discussion of Mycenaean identity, ${ }^{18}$ quite numerous potential cultural and ethnic diacritics have been put forward, including both, ideational and organizational aspects of the Mycenaean civilization such as language, the Linear B script, religion, the so-called "wanax ideology,"19 and mortuary practices, ${ }^{20}$ as well as different categories of artifacts and forms of architecture that mostly would also qualify as criteria proposed for the express purpose of characterizing the presence of the ethnic Mycenaeans in peripheral regi-

12 Heinhold-Krahmer 2007; Melchert, forthcoming.

13 Singer 2008.

14 Beckman, Bryce, Cline 20II: 267. Cf. also Cline 1994: 69; 1996: 145.

15 See, e.g., Bryce 1989a; 1989b; 2003; Cline 1991; 1994; 1996; 1998; 2010; Güterbock 1983; 1984; Helck 1987; Kelder 2004-2005; 2010; Mee 1978; 1998; Mountjoy 1998; Singer 1983; now also Fischer 2010; Beckman. Bryce, Cline 20II, all with many additional references.

16 E.g., Graves-Brown et al. 1996; Jones 1997; Morris 2000; Meskell, Preucel 2007; Insoll 2007.

17 Feuer 20II: 5II. Cf. also Jones 1996: 72-73.

18 For a summary, see Feuer 2011: 512-14.

19 Kilian 1988.

20 E.g, Cavanagh 1998. 
ons, first of all, tomb architecture, figurines, jewelry, and - last but not least - pottery. ${ }^{21}$ The latter, however, was a trade item, often locally manufactured by either itinerant craftsmen or even local potters who adopted Mycenaean technology and tradition. The mere presence of pottery, therefore, by itself does not indicate the presence of the ethnic Mycenaeans, unless found in association with other Mycenaean diacritics. ${ }^{22}$ Vanschoonwinkel, in his overview of Mycenaean expansion overseas, concurs that:

[T]here is no logical ethnic link between a type of vase and its owner or even maker, such a vessel cannot give information about the racial, linguistic, cultural or geographical identity of its user. ${ }^{23}$

Hence, the archaeological interpretations based essentially on pottery, as, for instance, the concept of the East Aegean - West Anatolian Interface proposed by Mountjoy, have considerable drawbacks. ${ }^{24}$ The majority of sites in western Anatolia where Mycenaean(-type) ceramics have been found yielded only single potsherds, therefore, placing them all on an equal footing in the analysis of the distribution of Mycenaean pottery may provide a misleading picture. The ratio of Mycenaean(-type) pottery to local wares, however, appears a more important diacritic. In Miletus V, for instance, which is characterized as almost entirely Mycenaean in culture, ${ }^{25}$ locally produced Mycenaean-type wares make up over $95 \%$ of the ceramic material, whereas farther to the north the ratio is less than $\mathrm{I} \%$ in Panaztepe and only $2 \%$ in Troy, which would not allow for extensive Mycenaean settlement at these sites. It may well be, of course, that such evidence, especially when associated with other Mycenaean diacritics (chamber tombs, figurines, etc.), represents the presence of the Mycenaeans, but conversely, the lack of such evidence at other sites cannot necessarily be used to signify their absence. Considering all the relevant archaeological data, I have concluded in another recent article:

Mycenaean settlement certainly did not cover vast territories in Anatolia. It seems to have been limited generally to the southern part of the Aegean coastal region [and the adjacent islands], with a number of colonies or enclaves, both ports of call and larger settlements, among which Miletus (Millawanda of Hittite texts) was by far the most important from the very beginning. ${ }^{26}$ ... The site became the main center of Minoan [Miletus IV] and subsequently Mycenaean culture in western Anatolia that exerted a strong impact on Anatolian population groups along the trade route in the Çine and Büyük Menderes region. ${ }^{27}$

Mycenaean-type, LH IIIB and LH IIIC, pottery (forming about $10 \%$ of the total sherd count), found during recent excavations at Cine-Tepecik, the Aydın province, in the strata roughly dated to the late-thirteenth and twelfth centuries $\mathrm{BC}$, indicates that this impact lasted till the very end of the Late Bronze Age. ${ }^{28}$ From the same layer (II ra) came also clay bullae with impressions of two Hittite stamp seals that confirm existence of the local administra-

21 Kilian 1990; Cline 1994. Cf. also Feuer 2011: 521-22.

22 Lambrou-Phillipson 1993; Sheratt 1999. Cf. also Feuer 2011: 522.

23 Vanschoonwinkel 2006: 92. Cf. also Taracha 2009: 22.

24 Mountjoy 1998.

25 E.g., Gödecken 1988; Greaves 2002; Niemeier 2005.

26 Taracha 2009: 21 .

27 Taracha 2009: 24 .

28 Günel 2010; Günel, Herbordt 2014 
tive system based on Hittite traditions, at the time when the site was part of the kingdom of Mira, subordinate to the Hittite great king. ${ }^{29}$ The finds from Çine-Tepecik indicate that emulation processes that resulted in acculturation and adoption of Mycenaean cultural influences by the genuine elites of southern Mira, stimulated by the existence of the trade route leading eastwards through the valleys of the Cine (Marsyas) stream and the Büyük Menderes (Meander) river, crossed here with the Hittite political impact on this vassal state in the second half of the thirteenth century BC. Furthermore, Hittite-like traits in materiat culture of the last LBA phase VI in Miletus confirm that at the time Millawanda was also open on Hittite cultural influences. ${ }^{30}$

How far this archaeological evidence may be compared and augmented with the texts? First issue to be dealt with is the presence of the ethnic Mycenaeans (Ahhiyawans) in Anatolia. Apart from three persons, Attarissiya, Kagamuna, ${ }^{31}$ and Tawagalawa (see infra), ${ }^{33}$ there is no reference in the Ahhiyawa texts to the ethnicity of individual people, not to mention population groups. We do not know, for instance, whether Atpa, who was in charge in Millawanda as a subordinate of the Ahhiyawan king in the first half of the thirteenth century BC (during the reigns of the Hittite kings Muwattali II, Urhi-Teššub/Mursili III, ca. 1272-1267, and Hattusili III, ca. 1267-1240), was an ethnic Mycenaean or rather a local Anatolian. Of whatever origin might Atpa be, for the most part of his rule he conducted an independent policy, supported by his father-in-law and a local petty king Piyamaradu (whose name is Luwian) who appears at least twice in our sources, under Muwattali II and in the usili III, as fomenter and leader of the anti-Hittite movements (see also below). ${ }^{33}$

More can be said about the Mycenaean expansion in southwestern Anatolia, at least in its early phase. The so-called Indictment of Madduwatta (CTH 147) confirms that the Mycenaeans had involved themselves in military operations in this region already in the late-fifteenth century BC (which is LH IIIAI in the Aegean), during the reign of Tudhaliya II (ca. 1420?-1400). ${ }^{34}$ The text mentions Attărissiya, a ruler or warlord of Ahhiya (to be understood rather in ethnic than in political terms), who is said to have chased a Hittite vassal named Madduwatta out of his country located most likely in eastern Caria and western Lycia. This may suggest that Attarissiya had installed himself on the Anatolian mainland with a significant military force at his command. The Hittite king rescued Madduwatta, but on, when Attarissiya attacked Madduwatta a second time, the Hittite army had to go in battle against 100 chariots of the Ahhiyawan commander reinforced by the infantry. On another occasion, the rascally Madduwatta cooperated with Attarissiya in raiding Alasiya (Cyprus). Both then must have had fleets of ships, hence Attarissiya exerted political control over some coastal territories in southwestern Anatolia. We do not know whether his land comprised Miletus as well, although his activities coincided with the emergence of the Mycenaean settlement in Miletus V. Archaeological finds from such sites as lasus, Müşgebi, and inland Mylasa indicate that Mycenaean settlement spread at the time throughout the whole region.

29 Günel, Herbordt 2010; 2014. Cf. also Taracha 2009: 24-26.

30 Greaves 2002: 48, 59-65.

31. For Kagamuna, who was probaby

1357), see, e.g., Hoffner 2009: 290.

32 See, however, in the following

33 Heinhold-Krahmer 1983; 1986. 
Attarissiya's designation as a ruler (LÚ) suggests that he was not viewed by the Hittites as a king (LUGAL), unlike the later king of Ahhiyawa in the thirteenth century $\mathrm{BC}$, who resided "across the sea" and whom the Hittite kings, starting from Muwattali II, regarded on equal terms as a "Great King," calling him "my brother" and "my peer." 35 We do not know whether Attarissiya was acting on the orders of any other Mycenaean king. It cannot be excluded, however, that either the political situation in the Aegean could have changed over time, or another center of power, maybe located in a different region of Mycenaean Greece, could have taken over the sea routes to Mycenaean enclaves in western Anatolia. Thus the meaning of the term "Ahhiyawa" may be different in texts from different periods, although, admittedly, it always has an ethno-geographical connotation, referring to the Mycenaean world and people living there (including Mycenaean settlers in the Aegean coastal area of western Anatolia and on the adjacent islands).

The archaeological evidence for a considerable Mycenaean presence in Miletus $\mathrm{V}$ does not reflect the unsteady political situation in the city from the mid-fourteenth through the second half of the thirteenth century BC that is known to us from the snapshots of the history of Millawanda/Milawata in the Ahhiyawa texts. A passage in the Extensive Annals of Mursili II is usually interpreted as referring to a Hittite attack on Millawanda. According to this interpretation, Millawanda, which formerly had been subject to the Hittites, shortly after Mursili's accession to the Hittite throne would have switched its allegiance to the king of Ahhiyawa. ${ }^{36}$ The defection of Millawanda met with response of the Hittite king. Two Hittite commanders captured the city in the third year of Mursili II's reign (1319), a casus belli that might correspond to the conflagration strata in Miletus V. Consequently, it has been suggested that the (first?) Hittite supremacy over Millawanda was connected with the conquests of Šuppiluliuma I in western Anatolia, when he also took Arzawa in vassalage.

Many scholars, both Hittitologists and archaeologists, consider this scenario to be an accomplished fact. The relevant passage in Mursili's Annals, however, is poorly prèserved and what is claimed to be a true situation is largely based on Götzes tentative restorations and his invention. As a matter of fact, as Popko recently pointed out, the Hittite troops could not attack Millawanda/Miletus prior to the definite victory over Arzawa, simply due to the topographical obstacles ${ }^{37}$ Moreover, the military operations in Millawanda described by Mursili might also be connected with Arzawan troops. Thus, there is no clear evidence for the Hittite supremacy over Millawanda before Tudhaliya IV (ca. 1240-1209).

Millawanda was rebuilt and the new settlement was still strongly Mycenaean in character. ${ }^{38}$ By the way, if the Mycenaean suzerain of the Millawanda dependency had ever changed, the Hittite raid of 1319 (or a period shortly after it) would be the time when it most likely had happened. Later on, Millawanda was controlled by the kingdom of Ahhiyawa. It is noteworthy that the first references to the king of Ahhiyawa (LUGAL KUR Ahhiya/uw $\bar{a}^{39}$ )

35 As in the so-called Tawagalawa Letter (KUB 14.3) from a Hittite king (probably Hattusili III) to the king of Ahhiyawa; see Beckman, Bryce, Cline 2011: 101-22. Cf. also below.

36 Beckman, Bryce, Cline 2011: 28-29, 45-46.

37 Popko 2010

38 Niemeier 2005.

39 The form Ahhiyuwā, consequently used in the Extensive Annals instead of Ahhiyawā of the Ten Year Annals and later sources, may suggest that the extended form of Ahhiya with the suffix $-u w a$ was at that time newly introduced on the model of Zalpa $>$ Zalpuwa. For a different interpretation of the Ahhivawā, see now Starke, forthcoming ("Die Umgestaltung von myken. Akhaiwiā ... zu Ahhijā- 
are found in the Annals of Muršili II. ${ }^{40}$ Beckman, Bryce and Cline adequately comment on this matter:

[I]n this context, the name Ahhiyawa is used specifically of a kingdom whose ruler became po- litically and perhaps military involved in western Anatolian affairs. ... Inevitably, Ahhiyawa's and Hatti's overlapping spheres of interest in the west led to tensions and perhaps on occasion conflicts between them. It seems likely, however, that Ahhiyawa sought to expand its influence and control in western Anatolia through alliances with local rulers, often at the expense of ties which these rulers had with Hatti, rather than by direct military action. ${ }^{41}$

As has been mentioned before, during the reign of the Hittite Great King Muwattali II, Millawanda was ruled by Atpa. At that time, in the I280s or early I270s BC, Atpa became also, even if temporarily, a superior of Manapa-Tarhunta, king of the Seha River Land, as a consequence of the latter's defeat at the hands of Piyamaradu, who also attacked Lazpa (Lesbos), certainly acting in cooperation with his son-in-law Atpa. We know that from a letter of Manapa-Tarhunta to Muwattali II (CTH I9I). ${ }^{42}$ Both attacks could only have come from the sea. From an archaeological perspective, if we agree that the Seha River Land was located in the Caicus valley, the Mycenaean presence in the region, including such sites as Panaztepe, might be associated with Millawanda's (temporary) "overlordship" in this area.

The same letter of Manapa-Tarhunta to Muwattali II alludes to a conflict over the region of Wilusa (usually identified as Troy and/or the Troad), in the course of which Muwattali had sent to Wilusa a Hittite expeditionary force led by a general named Kassu. Unfortunately, we have no record of the task and the outcome of this expedition. If, however, it was the same conflict which is recalled in the Tawagalawa Letter from the Hattusili III's reign, the Ahhiyawan king was also involved in it. Hence, a possible task of the Hittites could have been to liberate their Wilusan vassal from a foreign invader.

Note also in this connection the name of the Wilusan king, Alaksandu, with whom Muwattali II drew up a vassal treaty. ${ }^{43}$ As early as the 1920 , soon after Hittite had been deciphered, Alaksandu was linked to the Greek Aleksandros, the name used in the Iliad for the Trojan prince Paris. ${ }^{44}$ In his recent paper Kloekhorst speculates about the possible implications:

The use of a Greek name by the royal family of Wiluša indicates that the Wilušans must at the very least have had close links to the Greeks, and possibly even that Greeks had married into the royal family (which could possibly be compared to the legend of the Greek Helen who fall in love with Paris and left Sparta for Troy, causing the Greeks to launch an attack on Troy to get her back). ${ }^{45}$

und Ahhijawa- wird nur auf dem Hintergrund vorhandener luwischer Stammvarianten wie Adana- // Tlawa- ... und der zugehöringen Ethnika Adanawi-, Tlawi-, *Arzawi-verständlich.") 40 Ten-Year Annals (CTH 6I.I) § 25' (Beckman, Bryce, Cline 20II: 2-3); Extensive Annals (CTH 6I.II) $\$ \S$ I', I0' (Beckman, Bryce, Cline 2011: 28-29, 38-39).

41 Beckman, Bryce, Cline 2011: 46.

42 Hoffner 2009: 293-96; Beckman, Bryce, Cline 20II: 140-41.

43 Beckman 1999: 87-93. Cf. also Latacz 2004: 105-10.

44 E.g., Latacz 2004: 117 with note 14.

Klokhorst 2012 . 46 another speculative scenario, according to which Alaksandu could have been the son of one of Kukunni's Greek concubines, or "Kukunni adopted an exceptional man of Greek extraction." 
Could the above mentioned conflict over Wilusa in the reign of Muwattali II be connected with the legend of the Trojan War as well?

However that may be, it seems that the first decades of the thirteenth century $\mathrm{BC}$ were the heyday of the kingdom of Ahhiyawa that controlled Millawanda as its dependency and probably also other coastal enclaves north and south of the city, as well as some of the islands off the Anatolian coast, including Lesbos. Millawanda, however, always played a pivotal role in the Mycenaean expansion in the region, becoming a suzerain (even if temporarily) in relation to other local kingdoms. Such a conclusion, drawn from the textual evidence, is not at odds with the finds of LH IIIBI and LH IIIB2 pottery and other Mycenaean diacritics at many sites such as Troy, Beşik Tepe, Panaztepe, Çerkes Sultaniye, Miletus, Müşgebi, and Telmessos. ${ }^{46} \mathrm{In}$ fact, at least the territory of Millawanda/Miletus, although located overseas, might be considered at the time part of the Mycenaean cultural border zone (according to archaeological definitions).

A fragmentary letter (KUB 26.9I) from the archives in Hattusa, written in Hittite, which can be assigned to the authorship of a king of Ahhiyawa (its Hittite addressee was probably Muwattali II), is evidence for the diplomatic correspondence between both courts. ${ }^{47}$ It confirms also that both sides acknowledged each other as a peer.

The situation did not change until the mid-I250s BC or slightly later when the so-called Tawagalawa Letter (KUB I4.3) from a Hittite king (probably Hattusili III) to his Ahhiyawan counterpart was composed. ${ }^{48}$ Heinhold-Krahmer pointed out four passages from this text in which letters of the Ahhiyawan king or requests for them are mentioned. ${ }^{49}$ Furthermore, the letter announces the arrival of a certain Dabala-Tarhunta as a Hittite messenger to the Ahhiyawan king, which shows lively diplomatic relations between both countries. The surviving part of the text (its third and last tablet) describes the last anti-Hittite activities of the renegade Piyamaradu, who had continued to raid Hittite vassals in southwestern Anatolia. Chased by the Hittite king, he had fled first to Millawanda that was still ruled by Atpa in the name of the king of Ahhiyawa, and then to one of the islands just off the western coast controlled by Ahhiyawa. The letter requested in diplomatic terms his extradition.

It is, however, not Piyamaradu, but an Ahhiyawan person named Tawagalawa who is of great interest to us. In my recent paper I have reconsidered the key issue, namely, who was Tawagalawa whose name was given by Hittitologists to the document in question. ${ }^{50}$ To keep it in short here. Tawagalawa is mentioned in three passages of the text (KUB I4.3 i I-5; i 7174; ii 59-62). And I agree with the interpretation, which is increasingly commonly accepted, that he was referred to not only as a "brother" of the king of Ahhiyawa (ii $6 \mathrm{I}$ ) but also as a

46 Kelder 2004-2005: 58, 60, 62-63, 71, 74, 79.

47 Hoffner 2009: 290-92; Beckman, Bryce, Cline 2011: 134-39. Concerning a mechanism of exchange of diplomatic letters between Hatti and Ahhiyawa, H.C. Melchert (forthcoming) suggests tentatively that messages would have been conveyed in writing to the respective frontier outposts of each kingdom in its own language and script, that is Hittite and Linear B Greek respectively, where they were translated. However, as the Hittite king corresponded with his western Anatolian vassals in Hittite, it is very likely to have been the case of his correspondence with the king of Ahhiyawa as well. (Note also that Hittite was the language of the Arzawa royal chancellery in the exchange of diplomatic letters with Amenhotep III). If so, there could have been scribes working at the Ahhiyawa court who were competent in Hittite. For Hittite-Mycenaean diplomatic relations, see also Taracha, forthcoming.

48 Hoffner 2009: 296-313; Beckman, Bryce, Cline 20Ir: 101-22.

49 Heinhold-Krahmer 2007: 192.

50 Taracha 2015 . 
Great King (LUGAL GAL) and "mighty king" (sarkus LUGAL-us) (i 7I, 73-74). However, the surviving text does not lead directly to the conclusion, which has been assumed a priori in fact, that Tawagalawa preceded the letter's addressee on the throne of Ahhiyawa. In my opinion, the proper interpretation of the relevant passages favors an alternative, to wit, that he was a contemporary ruler of another Mycenaean kingdom. The term "brother" might denote his status as a royal peer of the Ahhiyawan king, rather than kinship. But even if both Mycenaean rulers had indeed been brothers, there is no reason why they could not have ruled over separate kingdoms. The case of the two brothers, Agamemnon and Menelaus, respective kings of Mycenae and Sparta, is telling.

The third tablet of the letter starts with the following reference to a turmoil in the Lukka lands caused by Piyamaradu's attacks (i I-5):

[Nex]t he (i.e. Piyamaradu) went (there) and destroyed the town Attarimma, and burned it down including the fortified royal compound. [Then] when the people of Lukka appealed to Tawagalawa, he went to those lands. They likewise appealed to me (i.e. Hattusili), so that I came down to those lands.

A straightforward interpretation of the passage leaves no doubt that it is the same casus belli. The text refers to Tawagalawa's campaign to the Lukka lands that must have occurred shortly before Hattusili's, seeing that both were called out by the Lukkeans in the face of the attack by Piyamaradu. Tawagalawa came first, maybe due to the fact that his land was closer to Lukka than Hatti. ${ }^{51}$ I have speculated elsewhere about the possible location of Tawagalawa's kingdom, suggesting the coastal islands in the southeastern Aegean, especially the Dodecanese, although Crete would still remain the best option. ${ }^{52}$

Such an assumption, if we agree that the Tawagalawa Letter refers to two different Mycenean rulers as Great Kings, weakens to an extent the vision put recently forward by Kelder, who equates Ahhiyawa with the entire Mycenaean world, including "the (larger part of the) Peloponnese, the Thebaid, various islands in the Aegean and Miletus on the Anatolian west coast, with Mycenae as its capital." ${ }^{53}$ As a matter of fact, Beckman, Bryce and Cline take a more plausible view:

[S]omeone like Agamemnon (or his real-life equivalent), who is described as "King of Kings" in the Iliad, could easily have been regarded by the Hittites as a Great King, despite the existence of other minor kings from the same general area. The beauty of this suggestion is that one is not forced to part ways with the evidence of the Linear B tablets for multiple small Mycenaean kingdoms (as one must do in following Kelder's argument for a "Great Mycenae"). ${ }^{54}$

51 Attarimma has now been plausibly identified by Rostislav Oreshko with Classical Loryma in the region of the Carian Chersonessos; cf. Rostislav Oreshko's paper "The last foothold of Arzawa. The problem of the location of Puranda and Mount Arinnanda revisited," read at the International Conference "Hrozný and Hittite: The First Hundred Years," Prague, II-I4 November 2015. I am also indebted to an as-yet-unpublished manuscript of Rostislav Oreshko (forthcoming). Thus, Attarimma (Loryma) controlled a maritime route from Lukka to the Aegean through the strait between the Carian Chersonessos and Rhodes. And that is why this troublesome region was so important to both the Hittites and Mycenaeans.

52 Taracha 2015: 284 .

53 Kelder 2010: 120. Cf. also Beckman, Bryce, Cline 20II: 4.

54 Beckman, Bryce, Cline 20II: 6. 
The Catalogue of Ships in the Iliad (II 499-773), which is regarded by scholars as an authentic piece reflecting Bronze Age realities, allows us to assume that there was enough room for at least several Great Kings in the LBA Aegean. The fleets put by the kings of Pylos (90), Tiryns (80), and Crete (80) (not to mention those of Lacedaimon [60], Boeotia [50], and Athenes [60]) almost equaled in number of ships that of Mycenae (I00).

Turning back to the Ahhiyawa texts, a letter sent in the late-thirteenth century BC by a Hittite king (probably Tudhaliya IV) to his western Anatolian vassal (probably Tarkasnawa, king of Mira), known as the Milawata Letter (CTH 182), refers to establishing new boundaries for Milawata by the Hittite king in consultation with his Miran subordinate, whose country bordered directly on it. ${ }^{55}$ It is generally agreed that by the time Milawata/Millawanda had been lost to the Ahhiyawan king and was now under Hittite suzerainty. ${ }^{56}$ Results of the excavations in Miletus seem to corroborate conclusions based on the textual data. The last LBA settlement in Miletus VI shows a mix of Mycenaean and possibly Hittite influences. ${ }^{57}$

The treaty (CTH 105) between Tudhaliya IV and Šaušga-muwa, king of Amurru, where the king of Ahhiyawa was included and then erased from the list of Great Kings, royal peers of the Hittite king, belongs also at the time when Ahhiyawa was no longer viewed as one of the Great Powers. ${ }^{58}$ Admittedly, the loss of peer status among the Great Kings by the king of Ahhiyawa must be taken as a(n immediate) result of the collapse of the Ahhiyawan kingdom, or generally, the Mycenaean palace system on the Greek mainland in the LH IIIB2 period, sometime in the thirties of the thirteenth century BC. ${ }^{59}$ In another passage of the same treaty, however, ships of Ahhiyawa are mentioned in association with the embargo being set up against Assyria, which may suggest that the trade relations between the Mycenaean world and the Levant had not been affected.

Two companion letters (RS 94.2530 and RS 94.2523) from the Urtenu archive in Ras Shamra/Ugarit, which were sent by the last Hittite Great King Šuppiluliuma II (ca. 1207${ }_{1178)}$ and a high official in his court called Benti-Šarruma to Ammurapi, king of Ugarit, indicate that Mycenaean-Hittite commercial relations lasted until the last days of the Hittite Empire. ${ }^{60}$ Šuppiluliuma requests Ammurapi to provide ships and let them take a cargo of metal ingots ${ }^{6}$ to be dispatched to the (A)hhiyawans awaiting the consignment in one of the ports in Lukka, that is somewhere on the Lycian or south Carian coast. It makes no matter here whether the "man of (A)hhiyawa" mentioned in the Šuppiluliuma's letter would have been a leader of Hittite mercenaries of (A)hhiyawan origin, as Bryce claims that he could be, or perhaps a Mycenaean of high status, who was under orders to take over the Hittite consignment in the name of his lord.

The Ugaritian cargo ships bound for Lukka were led by a certain Satalli, acting on the orders of the Hittite king. This late instance of the palace-directed sea commerce is not at odds with the general character of the LBA trade that was largely palace- and elite-directed,

55 Hoffner 2009: 313-2I; Beckman, Bryce, Cline 20II: 123-33.

56 For a different opinion, see Hoffner 2009: 315 ("The Milawata Letter suggests that Milawanda remained under Ahhiyawan control in the reign of Tudhaliya IV").

57 See n. 30.

58 Beckman 1999: 103-07; Singer 2003: 98-100; Beckman, Bryce, Cline 2011: 50-68.

59 For the political context of the treaty that Tudhaliya drew up with Šaušga-muwa at the beginning of the latter's reign (ca, 1235), see Singer 1991: 172-73.

60 Singer 2006; Bryce 2010. Cf. also Beckman, Bryce, Cline 2011: 253-62.

61 Which is I. Singer's (2006) translation of the logogram PAD.MEŚ. 
comprising gift exchange and organized trade providing important raw materials and luxury items. ${ }^{62}$ The ship wrecked around $1200 \mathrm{BC}$ at Cape Gelidonya at the western entrance of the Pamphylian Gulf, which, among others, carried about one ton of copper ingots, some bronze scrap-metal, and small quantities of tin and lead, may give us an idea of how such ships looked like. ${ }^{63}$ Concerning Mycenaean-Hittite trade relations, I drew elsewhere the following conclusion:

On the textual evidence the Hittites, whose homeland was landlocked, engaged in sea commerce through their own merchants or through intermediaries operating in the ports of southeastern Anatolia and the Levant. Both documentary and archaeological data indicate that Ugarit became the most important port in the region. ${ }^{64}$...All the evidence indicates that the bulk of commercial contact between the Mycenaean world and Hittite Anatolia was of a rather indirect nature, going via northern Syria and Cilicia. Despite the suggestions of Cline, ${ }^{65}$ Korfmann ${ }^{66}$ and others, there is no evidence for overland trade routes from the Hittite homeland to the western coast of Anatolia. ${ }^{67}$

As Ugarit in the Levant, Miletus remained probably the most important commercial port in the coastal region of western Anatolia. LH IIIC pottery found at a number of sites along the coast, as well as at inland sites such as Cine-Tepecik, indicates that the Mycenaeans/ early Greeks still maintained contacts with the natives and most likely kept settling there, although Ahhiyawa's influence had waned, if not ceased entirely. There can be no doubt that the Great Colonization of the first millennium BC took its rise in Mycenaean settlement processes that had started in western Anatolia and on the adjacent islands by $1300 \mathrm{BC}$.

\section{Bibliography}

Alparslan 2005 - Alparslan M. 2005: Einige Überlegungen zur Ahhiyawa-Frage. In A. Süel (ed.), V. Uluslararası Hititoloji Kongresi Bildirileri: Çorım, 02-08 Eylül 2002 / Acts of the Vth International Congress of Hittitology: Corum, September 02-08, 2002, Ankara, Nokta Ofset: 33-41.

Bass 1967 - Bass G.F. 1967: Cape Gelidonya: A Bronze Age Shipwreck. Transactions of the American Philosophical Society 57, pt. 8. Philadelphia: American Philosophical Society.

Bass 1991 - Bass G.F. 1991: Evidence of Trade from Bronze Age Shipwrecks. In N.H. Gale (ed.), Bronze Age Trade in the Mediterranean, Jonsered, Aströms: 69-82.

Beckman 1999 - Beckman G. 1999: Hittite Diplomatic Texts. Writings from the Ancient World 7. 2nd ed. Atlanta: Society of Biblical Literature.

Beckman, Bryce, Cline 2011 - Beckman G., Bryce T.R., Cline E.H. 2011: The Ahhiyawa Texts. Writings from the Ancient World 28. Atlanta: Society of Biblical Literature.

Branigan 1981 - Branigan K. 1981: Minoan Colonialism. BSA 76: 23-33.

Branigan 1981 - Branigan, K. 1984: Minoan Community Colonies in the Aegean. In R. Hägg, N. Marinatos (eds), The Minoan Thalassocracy: Myth and Reality. Proceedings of the Third International Symposium at the Swedish Institute in Athens, 31 May - 5 June, 1982. SkrAth 4ㅇ, 32. Göteborg, Paul Åströms Förlag: 49-53.

Bryce 1989a - Bryce T. 1989: Ahhiyawans and Mycenaeans - An Anatolian Viewpoint. OJA 8: $257-$ 310.

62 E.g., Kolb 2004: 579-83, with references to the earlier literature.

63 Bass I967; 1991: 69-74.

64 Till its ultimate fall in the early seventies of the twelfth century BC. See now Cline 2015.

65 Cline 1994: 71.

66 Korfmann 200I.

67 Taracha 2006: 147-48. Cf. also Kolb 2004. 
Bryce T. 1989b - Bryce T. 1989: The Nature of Mycenaean Involvement in Western Anatolia. Historia 38: $1-21$.

Bryce 2003. - Bryce T. 2003: Relations between Hatti and Ahhiyawa in the Last Decades of the Bronze Age. In G. Beckman, R. Beal, G. McMahon (eds), Hittite Studies in Honor of Harry A. Hoffner Jr. on the Occasion of His 65th Birthday. Winona Lake, Ind., Eisenbrauns: 59-72.

Bryce 2010 - Bryce T. 2010: The Hittite Deal with the Hiyawa-Men. In Y. Cohen, A. Gilan, J.L. Miller (eds), Pax Hethitica: Studies on the Hittites and their Neighbours in Honour of Itamar Singer. Studien zu den Boğazköy-Texten 51. Wiesbaden, Harrassowitz: 47-53.

Cavanagh 1998 - Cavanagh W. 1998: Innovation, Conservatism and Variation in Mycenaean Funerary Ritual. In K. Branigan (ed.), Cemetery and Society in the Aegean Bronze Age. Sheffield Studies in Aegean Archaeology 1. Sheffield, Sheffield Academic Press: 103-14.

Cline 1991 - Cline E.H. 1991: Hittite Objects in the Bronze Age Aegean. AnSt 41: 133-43.

Cline 1994 - Cline E.H. 1994: Sailing the Wine-Dark Sea: International Trade and the Late Bronze Age Aegean. BAR International Series 591. Oxford: British Archaeological Reports.

Cline 1996 - Cline E.H.1996: Assuwa and the Achaeans: the 'Mycenaean' Sword at Hattusa and Its Possible Implications. BSA 91: 137-51.

Cline 1998 - Cline E.H. 1998: Amenhotep III, the Aegean and Anatolia. In D. O'Connor, E.H. Cline (eds), Amenhotep III: Perspectives on his Reign. Ann Arbor, University of Michigan Press: 236-50.

Cline 2010 - Cline E.H. 2010: Bronze Age Interactions between the Aegean and the Eastern Mediterranean Revisited: Mainstream, Margin, or Periphery. In W. Parkinson, M. Galaty (eds), Archaic State Interaction: The Eastern Mediterranean in the Bronze Age: Santa Fe, N.M., School for Advanced Research: 161-80.

Cline 2015 - Cline E.H. 2015: 1177 B.C.: The Year Civilization Collapsed. Turning Points in Ancient History. 2nd revised edition. Princeton-Oxford: Princeton University Press.

Feuer 1999 - Feuer B. 1999: The Mycenaean Periphery: Some Theoretical and Methodological Considerations. In N. Kyparissi-Apostolika, M. Papakonstantinou (eds), The Periphery of the Mycenaean World: 2nd International Interdisciplinary Colloquium. 26-30 September, Lamia 1999 / H

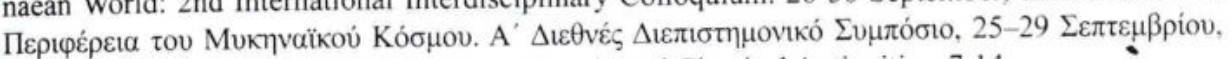
$\Lambda \alpha \mu i \alpha$ 1994. Athens: 14th Ephorate of Prehistoric and Classical Antiquities: 7-14.

Feuer 2003 - Feuer B. 2003: Cultural Interaction Processes in the Mycenaean Periphery. In N. Kyparissi-Apostolika, M. Papakonstantinou (eds), The Periphery of the Mycenaean World: 2nd Interna-

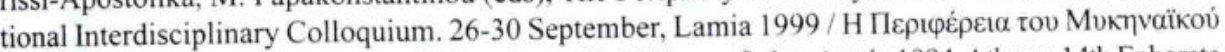

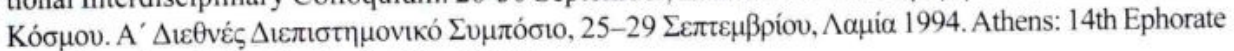
of Prehistoric and Classical Antiquities: 15-24.

Feuer 2011 - Feuer B. 2011: Being Mycenaean: A View from the Periphery. AJA 115: 507-36.

Fischer 2010 - Fischer R. 2010: Die Ahhijawa-Frage: Mit einer kommentierten Bibliographie. Dresdner Beiträge zur Hethitologie 26. Wiesbaden: Harrassowitz.

Gödecken 1988 - Gödecken K.B. 1988: A Contribution to the Early History of Miletus: The Settlement in Mycenaean Times and its Connections Overseas. In E.B. French, K.A. Wardle (eds), Problems in Greek Prehistory: Papers Presented at the Centenary Conference of the British School of Archaeology at Athens, Manchester, April 1986. Bristol, Bristol Classical Press: 307-318.

Graves-Brown, Jones, Gamble 1996 - Graves-Brown P., Jones S., Gamble C. (eds), 1996: Cultural Identity and Archaeology: The Construction of European Communities. London: Routledge.

Greaves 2002 - Greaves A.M. 2002: Miletos: A History. London: Routledge.

Günel 2010 - Günel S. 2010: Mycenaean cultural impact on the Çine (Marsyas) plain, southwest Anatolia: the evidence from Cine-Tepecik. AnSt 60: 25-49.

Günel, Herbordt 2010 - Günel S., Herbordt S. 2010: Ein hethitischer Siegelabdruck aus Çine-Tepecik. AA: $1-11$.

Günel, Herbordt 2014 - Günel S., Herbordt S. 2014: Mykenische Kraterfragmente mit figürlichen Darstellungen und ein hethitischer Siegelabruck aus der spätbronzezeitlichen Siedlung von ÇineTepecik. AA: 1-14. 
Güterbock 1983 - Güterbock H.G. 1983: The Hittites and the Aegean World: 1. The Ahhiyawa Problem Reconsidered. AJA 87: 133-38.

Güterbock 1984 - Güterbock H.G. 1984: Hittites and Akhaeans: A New Look. PAPS 128: 114-22.

Hawkins 2009 - Hawkins J.D. 2009: The Arzawa letters in recent perspective. BMSAES 14: 74-83.

Heinhold-Krahmer 1977 - Heinhold-Krahmer S. 1977: Arzawa: Untersuchungen zu einer Geschichte nach den hethitischen Quellen. Texte der Hethiter 8. Heidelberg: Winter.

Heinhold-Krahmer 1983 - Heinhold-Krahmer S. 1983: Untersuchungen zu Piyamaradu I. Orientalia 52: $81-87$.

Heinhold-Krahmer 1986 - Heinhold-Krahmer S. 1986: Untersuchungen zu Piyamaradu II. Orientalia 55: 47-62.

Heinhold-Krahmer 2007 - Heinhold-Krahmer S. 2007: Zu diplomatischen Kontakten zwischen dem Hethiterreich und dem Land Ahhiyawa. In E. Alram-Stern, G. Nightingale (eds), Keimelion: Elitenbildung und elitärer Konsum von der mykenischen Palastzeit bis zur homerischen Epoche / The Formation of Elites and Elitist Lifestyles from Mycenaean Palatial Times to the Homeric Period. Akten des internationalen Kongresses vom 3. bis 5. Februar 2005 in Salzburg. Wien, Verlag der Österreichischen Akademie der Wissenschaften: 191-207.

Helck 1987 - Helck W. 1987: Zur Keftiu-, Alašia- und Ahhijawa-Frage. In H.G. Buchholz, Ägäische Bronzezeit. Darmstadt, Wissenschaftliche Buchgesellschaft: 218-26.

Hoffner 2009 - Hoffner H.A. Jr. 2009: Letters from the Hittite Kingdom. Writings from the Ancient World 15. Atlanta: Society of Biblical Literature.

Insoll 2007 - Insoll T. ed. 2007: The Archaeology of Identities: A Reader. Abingdon: Routledge.

Jones 1996 - Jones S. 1996: Discourses of Identity in the Interpretation of the Past. In Graves-Brown et al. 1996: 62-80.

Jones 1997 - Jones S. 1997: The Archaeology of Ethnicity: Constructing Identities in the Past and Present. London: Routledge.

Kelder 2004-2005 - Kelder J.M. 2004-2005: Mycenaeans in Western Anatolia. Talanta 36-37: 49-88.

Kelder 2010 - Kelder J.M. 2010: The Kingdom of Mycenae: A Great Kingdom in the Late Bronze Age Aegean. Bethesda, MD: CDL.

Kilian 1988 - Kilian K. 1988: The Emergence of the Wanax Ideology in the Mycenaean Palaces. OJA 7: 291-302.

Kilian 1990 - Kilian K. 1990: Mycenaean Colonization: Norm and Variety. In J.-P. Descoeudres (ed.), Greek Colonists and Native Populations: Proceedings of the First Australian Congress of Classical Archaeology Held in Honour of Emeritus Professor A.D. Trendall, Sydney, 9-14 July 1985. Oxford, Clarendon Press: 445-67.

Kloekhorst 2012 - Kloekhorst A. 2012: The Language of Troy. In J. Kelder, G. Uslu, Ö.F. Şerifoğlu (eds), Troy: City, Homer, Turkey. Amsterdam, W Books: 46-50.

Kolb 2004 - Kolb F. 2004: Troy VI: A Trading Center and Commercial City?. AJA 108: 577-614.

Korfmann 2001 - Korfmann M. 2001: Troia als Drehscheibe des Handels im 2. und 3. vorchristlichen Jahrtausend. In Troia - Traum und Wirklichkeit, edited by Archäologisches Landesmuseum BadenWürttemberg. Stuttgart, Konrad Theiss: 355-68.

Lambrou-Phillipson 1993 - Lambrou-Phillipson C. 1993: The Limitations of the Pottery Model in the Identification of Trading Colonies. In C. Zerner, P. Zerner, J. Winder (eds), Wace and Blegen: Pottery as Evidence for Trade in the Aegean Bronze Age, 1939-1989. Proceedings of the International Conference Held at the American School of Classical Studies at Athens, Athens, December 2-3, 1989. Amsterdam, J.C. Gieben: 365-68.

Latacz 2004 - Latacz J. 2004: Troy and Homer: Towards a Solution of an Old Mystery. Oxford: Oxford University Press.

Mee 1978 - Mee C. 1978: Aegean Trade and Settlement in Anatolia in the Second Millennium B.C. AnSt 28: 121-55. 
Mee 1998 - Mee C. 1998: Anatolia and the Aegean in the Late Bronze Age. In E.H. Cline, D. Harris-Cline (eds), The Aegean and the Orient in the Second Millennium: Proceedings of the 50th Anniversary Symposium, Cincinnati, 18-20 April 1997. Aegaeum 18. Liège, Université de Liège: $137-48$.

Melchert forthcoming - Melchert H.C. forthcoming: Mycenaean and Hittite Diplomatic Correspondence: Fact and Fiction. In A. Teffeteller (ed.), The proceedings of the workshop "Mycenaeans and Anatolians in the Late Bronze Age" held in Montreal, Quebec, January 4-5, 2006. Oxford: Oxford University Press. (available online at www.linguistics.ucla.edu/people/Melchert/montrealtext.pdf)

Meskell, Preucel 2007 - Meskell L., Preucel R.W. (eds), 2007: A Companion to Social Archaeology. Oxford-Malden: Blackwell.

Miller 2010 - Miller J.L. 2010: Some Disputed Passages in the Tawagalawa Letter. In I. Singer (ed.), ipamati kistamati pari tumatimis: Luwian and Hittite Studies Presented to J. David Hawkins on the Occasion of His 70th Birthday. Tel Aviv University, Institute of Archaeology Monograph Series 28. Tel Aviv, Emery and Claire Yass Publications in Archaeology: 159-69.

Morris 2000 - Morris I. 2000: Archaeology as Cultural History: Words and Things in Iron Age Greece. Oxford-Malden: Blackwell.

Mountjoy 1998 - Mountjoy P.A. 1998: The East Aegean-West Anatolian Interface in the Late Bronze Age. AnSt 48: 33-67.

Niemeier 2005 - Niemeier W.-D. 2005: Minoans, Mycenaeans, Hittites and Ionians in western Asia Minor: new excavations in Bronze Age Miletus-Millawanda. In A. Villing (ed.), The Greeks in the East. British Museum Research Publications 157. London, British Museum Press: 1-36.

Oreshko forthcoming - Oreshko R. forthcoming: Geography of the Western Fringes: Gar(a)giša / Gargiya and the Lands of the Late Bronze Age Caria. In O. Henry, K. Konuk (eds), Proceedings of the Conference 'Karia Arkhaia. La Carie, des origines à la période pré-hékatomnide' (Istambul, November 14-16, 2013). Istambul.

Popko 2010 - Popko M. 2010: Hethiter und Ahhijawa: Feinde? In Y. Cohen, A. Gilan, J.L. Miller (eds), Pax Hethitica: Studies on the Hittites and their Neighbours in Honour of Itamar Singer,. Studien zu den Boğazköy-Texten 51.Wiesbaden, Harrassowitz: 284-289.

Rehak 1997 - Rehak P. 1997: Interconnections between the Aegean and the Orient in the Second Millennium. AJA 101: 399-402.

Sherratt 1999 - Sherratt S. 1999: E Pur Si Muove: Pots, Markets and Values in the Second Millennium Mediterranean. In J.P. Crielaard, V. Stissi, G.J. van Wijngaarden (eds), The Complex Past of Pottery: Production, Circulation and Consumption of Mycenaean and Greek Pottery (Sixteenth to Early Fifth Centuries BC). Proceedings of the ARCHON International Conference, Held in Amsterdam, 8-9 November, 1996. Amsterdam, J.C. Gieben: 163-211.

Singer 1983 - Singer I. 1983: Western Anatolia in the Thirteenth Century B.C. according to the Hittite Sources. AnSt 33: 205-17.

Singer 1991 - Singer I. 1991: A Concise History of Amurru. In S. Izre'el, Amurru Akkadian: A Linguistic Study. Vol. 2, 134-95. Harvard Semitic Studies 41. Atlanta, Georgia: Scholars Press.

Singer 2003 - Singer 1. 2003: The Treaties between Hatti and Amurru. In W.W. Hallo, K.L. Younger, Jr. (eds), The Context of Scripture: Monumental Inscriptions from the Biblical World. Vol. 2. LeidenNew York, Brill: 93-100.

Singer 2006 - Singer I. 2006: Ships Bound for Lukka: A New Interpretation of the Companion Letters RS 94.2530 and RS 94.2523. Altorientalische Forschungen 33: 242-62.

Singer 2008 - Singer I. 2008: Purple-Dyers in Lazpa. In B.J. Collins, M.R. Bachvarova, I. Rutherford (eds), Anatolian Interfaces: Hittites, Greeks and Their Neighbors. Proceedings of an International Conference on Cross-Cultural Interaction, September 17-19, 2004, Emory University, Atlanta, GA. Oxford, Oxbow: 21-43.

Starke forthcoming - Starke F. forthcoming: Zu Ansatz, Lautung und Herkunft einiger luwischer Ländernamen des 12.-8. Jh. In N. Bolatti-Guzzo, P. Taracha (eds), "And I Knew Twelve Languages:" A Tribute to Massimo Poetto on His 70th Birthday. Warsaw: Agade. 
Taracha 2006 - Taracha P. 2006: Mycenaeans in Anatolia and Ahhiyawa of Hittite Texts: A Re-Assessment. Archeologia 57: 143-49.

Taracha 2009 - Taracha P. 2009: New Light on Relations between the Mycenaean World and Hittite Anatolia. Archeologia 60: 19-26.

Taracha 2015 - Taracha P. 2015: Mycenaean peer(s) of the king of Ahhiyawa? A note on the Tawagalawa Letter. In A. Müller-Karpe, E. Rieken, W. Sommerfeld (eds), Saeculum: Gedenkschrift für Heinrich Otten anlässlich seines 100. Geburtstags. Studien zu den Boğazköy-Texten 58. Wiesbaden, Harrassowitz: 279-287.

Taracha forthcoming - Taracha P. forthcoming: On the Nature of Hittite Diplomatic Relations with Mycenaean Rulers. In R. Koliński, J. Prostko-Prostyński, W. Tyborowski (eds), Awīlum ša ana la mašê, "A man not to be forgotten:" Studies in Ancient Economy and Society Presented to Prof. Stefan Zawadzki on the Occasion of His 70th Birthday. Münster: Ugarit-Verlag.

Tartaron 2005 - Tartaron T.F. 2005: Glykys Limin and the Discontinuous Mycenaean Periphery. In R. Laffineur, E. Greco (eds), Emporia: Aegeans in the Central and Eastern Mediterranean. Proceedings of the 10th International Aegean Conference, Athens, Italian School of Archaeology, 14-18 April 2004. Aegaeum 25. Liège - Austin, Université de Liège and University of Texas at Austin: 153-60.

Vanschoonwinkel 2006 - Vanschoonwinkel J. 2006: Mycenaean Expansion. In G. Tsetskhladze (ed.), Greek Colonisation: An Account of Greek Colonies and Other Settlements Overseas. Vol. I. Leiden-Boston, Brill: 41-113. 
81) Corrigenda to Schmidtchen, E., Simplicia and Unpublished Fragments of Alamdimmû from the British Museum, in: Panayotov, S. V./Vacín, L. (eds.) Mesopotamian Medicin and Magic. Studies in Honor of Markham J. Geller, AMD 14, 2018, Leiden/Boston: Brill, p. 462-500 - I am much obliged to Henry Stadhouders for spotting some unfortunate mistakes of mine within the discussed paper as well as for sharing his corrections with me. These and some minor corrections from my part are presented below.

p. 470 and 489: K. 7198 instead of K. 7189.

p. 477 (K. 8920) 1. 8': read maš-re-e instead of par-re-e.

p. 480f. (K. 7958) 1. 5': restore most likely ' $u \check{s}$-te $e^{\top}-[(n e ́)-e s ̦-s ̦ i]$ after É.'GAL'?

ibid. 1. 7': read ${ }^{\top} \mathrm{GEN}_{7}{ }^{1}$ su-ru-um-mi "like $s$-intestines", which may refer to the coiled condition or appearance of the surface of the respective body part, maybe the tongue.

ibid. 1. 8': $\mathrm{SIG}_{7} \mathrm{ma}$-SI-at might be either a defective or playful writing for urqa malât "is full (of yellow)". The following qar-sign might belong to qar-[rad $]$ "(he is) a warrior".

ibid. 1. 10': The interpretation as pa-ris (pāris) "he is resolute; the one who decides" or similar seems not out of place. ibid. $1.11^{\prime}$ : restore $r a-i-\ulcorner m i\urcorner[T U K(-s ̌ i)]$.

ibid. 1. 12': much likely to be read NINDA at-ra $\{\mathrm{x}\}\left[\mathrm{GU}_{7}\right]$ or together with an unmarked variant like NINDA at-ra $<:>{ }^{[N I N D A}{ }^{\top}\left[\right.$ nap-šá $\left.{ }^{G} \mathrm{GU}_{7}\right]$ or similar.

ibid. 1. 15': read possibly an-ni šil-la- ${ }^{\top} t i{ }^{\top}$ "punishment for insolence".

p. 481, 1. 11': translate "he will lack food" for NINDA i-ber-ri.

ibid. 1. 16': the first apodosis has probably to be translated "he consumes bread/food without exertion".

p. 484 (K. 7956) 1l.13', 15', 17': read DIŠ MIN 2 MIN at the beginning.

p. 487 (K. 17899) 1l. 1', 6': read DU 11 instead of KA.

ibid. 1. 11': restore [i-šal-lim] at the end of the line, following the new fragment BM 39172 presented on p. 217f. in Fincke, J., Of tirku, Moles and Other Spots on the Skin according to the Physiognomic Omens, in: Studies in Honor of Markham J. Geller, AMD 14, 2018, p. 203-231.

p. 493 (first line): K. 10812 instead of K. 108112.

ibid. (K. 8625) 1. 7': read $a p-p a-\ulcorner r a t$ " "it (the hair) is tufted".

ibid. 1. 9': read $k u-{ }^{\top} u ́ s-s a^{\top}-[a t]$ instead of $k u-{ }^{\top} u s-s a^{\top}-[a t \ldots]$.

p. 499 (K. 5651) 1. 6': read ' $k u^{\top}-u m-m u-d a$ which is in accordance with the traces given in SpTU IV, 149 ii 19 (emended in Böck, B., Die babylonisch-assyrische Morphoskopie, AfO Beiheft 27, 2000, p. 158 1. 126 to šu-um-mu-ța). See similar also TBP 28:7' (referring to the fingers) and TBP 11c vi 23' (cf. Böck, B., Die babylonisch-assyrische Morphoskopie, AfO Beiheft 27, 2000, p. 156 1. 107 referring to the hands). For the possible meaning here as "woven/interwoven (lines of the hand?)" see CAD K, 108.

Eric SCHMIDTCHEN <eric.schmidtchen@gmx.de>

82) Corrigenda to Foster, Sargonic and Pre-Sargonic Cuneiform Texts in the Yale Babylonian Collection (2020) - p. 4 third paragraph should read: No tablet at Yale has so far been securely identified as having come from Abu Habba (Sippar), though No. 212 (NBC 10207), which may have been part of the "Quradum Archive," seems a strong possibility. Texts: read with copies against indices, 129.8 inim šeš-nita "at the word of his brother," 131 ii 2 šeš-ni "his brother," 198.2 Šeš-kur-ra.

Benjamin R. FOSTER

83) Corrections concerning two publications resulting from the project 'The Trojan Catalogue (Hom. Il. 2.816-877) and the Peoples of western Anatolia in the Late Bronze Age and Early Iron Age' - We would like to add the following information to each of the two publications listed below: 'The paper is written as a part of project "The Trojan Catalogue (Hom. Il. 2.816-877) and the Peoples of western Anatolia in the Late Bronze Age and Early Iron Age. A Study of the Homeric Text in the Light of Hittite Sources and Classical Geographical Tradition" (2015/19/P/HS3/04161), which has received funding from the European Union's Horizon 2020 research and innovation program under the Marie Skłodowska-Curie grant agreement No 665778 with the National Science Centre, Poland (POLONEZ 1, 2016-2018)'. The two publications in question are: 
1) Taracha, P. Approaches to Mycenaean-Hittite Interconnections in the Late Bronze Age, in: Ł. Niesiołowski-Spanò - M. Węcowski (eds.), Change, Continuity, and Connectivity. NorthEastern Mediterranean at the Turn of the Bronze Age and in the Early Iron Age, Wiesbaden: Harrassowitz, 2018: 8-22.

2) Taracha, P. On the Nature of Hittite Diplomatic Relations with Mycenaean Rulers, in: R. Koliński J. Prostko-Prostyński - W. Tyborowski (eds.), Awīlum ša la mašê - man who cannot be forgotten. Studies in Honor of Prof. Stefan Zawadzki Presented on the Occasion of his 70th Birthday (AOAT 463), Münster: Ugarit Verlag, 2018: 215-230.

We also would like to use the opportunity to draw your attention to the project internet site at which a description of its principal results, as well as links to all resulting publications may be found: http://orient.uw.edu.pl/project-trojan-catalogue-oreshko_rostislav/. For further information please feel free to contact the principal investigator of the project (R. Oreshko).

Rostislav ORESHKO <r.oreshko@hum.leidenuniv.nl> Leiden University/Center for Hellenic Studies Washington, DC (USA)

PiotrTARACHA <piotr.taracha@uw.edu.pl> University of Warsaw (POLAND)

\section{VIE DE L’ASSYRIOLOGIE}

84) A note to our colleagues - The editorial board of the Occasional Publications of the Museum of the Sealand wishes to advise and remind colleagues that work published in OPMS is for satirical purposes only, including the past titles "Making Sumer Great Again" and "Already Tired of Winning: New Akkadian Prophecy Texts." While we remain committed to the important purpose of amusing our colleagues, we do not wish for them to think that its articles or book reviews contain even one ounce of truth. And so we urge all to take notice of (and enjoy) the fictitious, fabricated, and facetious nature of these and future works.

Submissions of new work may be sent for consideration to OPMS at: opmseditors@gmail.com.

C. Jay CRISOSTOMO, University of Michigan Steven GARFINKLE, Western Washington University

Gina KONSTANTOPOLOUS, University of Tsukuba Seth RICHARDSON, University of Chicago 